\title{
Visitor Behavior in the Library of Syiah Kuala University based on Their Visiting Time Duration
}

\author{
Samsul Anwar*, Afriyani, Putri Shalihatul Ula, Isra Safriana, Ida Fajri, Reza Ariska \\ Jurusan Statistika, Fakultas MIPA, Universitas Syiah Kuala \\ *email: samsul.anwar@unsyiah.ac.id
}

\begin{abstract}
The main requirements in the application of survival analysis are the starting time and the ending time of an event. Thus, the duration of visiting time in the Library of Syiah Kuala University (Unsyiah) Banda Aceh could be analyzed by using survival analysis. This study obtained primary data through an interview with the visitors of Unsyiah's library. Total Samples were 105 visitors collected from three different floors of the library that is 35 visitors from each floor. The analysis was divided into two main steps. The first step was estimating the probability distribution of the visit time duration data through graphical analysis. The second step was calculating the probability density function (PDF), cumulative density function (CDF), survival, and hazard function of the data based on the appropriate distribution in the first step. Visitor behavior could be seen from the function of probabilities, survival and hazard of their visiting time duration. The PDF showed that the visitors tended to have smaller probabilities for being at the library when their visiting time duration increased, as well as their probabilities for staying after spending time of $t$ hours that indicated with the survival function. On the other hand, they could leave the library anytime with the same rate at 0.5259 according to the hazard function. In additional, the median estimation of visiting time duration based on the exponential distribution was really closed to the sample median that is 2.5 hours.
\end{abstract}

Keywords: $C D F$, graphical analysis, hazard function, PDF, probability distribution, survival analysis, survival function, visiting time duration.

\begin{abstract}
ABSTRAK
Syarat utama dalam aplikasi analisis survival adalah adanya waktu awal (starting time) dan waktu berakhirnya (ending time) suatu peristiwa. Dengan demikian, data lama waktu kunjungan di UPT. Perpustakaan Universitas Syiah Kuala (Unsyiah) Banda Aceh dapat dianalisa dengan menggunakan analisis survival. Penelitian ini menggunakan data primer melalui wawancara langsung dengan pengunjung UPT. Perpustakaan Unsyiah. Jumlah sampel yang diambil adalah sebanyak 105 orang pengunjung dengan masing-masing sebanyak 35 orang untuk setiap lantainya. Analisa dalam penelitian ini terbagi atas dua langkah utama. Pertama, melakukan estimasi distribusi peluang dari data lama waktu kunjungan di perpustakaan dengan menggunakan graphical analysis. Langkah kedua adalah menghitung nilai fungsi probabilitas densitas (PDF), probabilitas kumulatif $(C D F)$, survival dan hazard dari data lama waktu kunjungan di UPT. Perpustakaan Unsyiah dengan menggunakan distribusi yang bersesuai pada langkah pertama. Perilaku pengunjung perpustakaan dapat dilihat dari fungsi probabilitas, survival dan hazard dari data lama waktu kunjungan mereka. PDF menunjukan bahwa pengunjung cenderung memiliki peluang yang lebih kecil untuk berada di perpustakaan ketika lama waktu kunjungan mereka meningkat, sama halnya dengan peluang mereka untuk tetap berada disana setelah menghabiskan waktu selama t jam di perpustakaan yang diindikasikan
\end{abstract}

Visitor Behavior in the Library of Syiah Kuala University based on

Their Visiting Time Duration

(Samsul Anwar, Afriyani, Putri Shalihatul Ula, Isra Safriana, Ida Fajri, Reza Ariska) 
dengan fungsi survival. Disisi lain, pengunjung dapat meninggalkan perpustakaan kapan saja dengan kelajuan yang sama yaitu sebesar 0,5259 berdasarkan fungsi hazard. Sebagai tambahan, nilai estimasi median data lama waktu kunjungan berdasarkan distribusi eksponensial sangat mendekati nilai sampel median sebenarnya yaitu selama 2,5 jam.

Kata kunci: analisis survival, CDF, distribusi eksponensial, distribusi peluang, fungsi hazard, fungsi survival, graphical analysis, lama waktu kunjungan, PDF.

\section{Pendahuluan}

Analisis survival atau analisis

data ketahanan hidup adalah suatu metode statistik untuk menganalisis data dengan variabel terikat yang diperhatikan berupa waktu sampai terjadinya suatu kejadian (Kleinbaum, dkk, 2005). Variabel yang menyatakan jangka waktu dari awal pengamatan dimulai hingga kejadian yang diinginkan terjadi pada suatu objek disebut waktu kegagalan atau failure time. Analisis survival memiliki tiga tujuan utama. Pertama, mengestimasi dan menginterpretasi peluang individu mengalami kejadian sesaat yang dinyatakan dalam bentuk fungsi hazard dan peluang suatu individu mengalami kejadian setelah atau pada suatu titik waktu yang dinyatakan dalam bentuk fungsi survival. Kedua, membandingkan fungsi survival dan fungsi hazard pada dua atau lebih kelompok. Ketiga, mengetahui hubungan antara waktu survival dengan variabel-variabel yang diduga mempengaruhi waktu survival. Beberapa contoh umum kejadian yang diamati dalam analisis survival diantaranya: kematian, serangan suatu wabah penyakit, tingkat kesembuhan seorang pasien setelah diberikan obat tertentu, serta kejadian lainnya dalam bidang kedokteran. Selain itu, analisis survival juga bisa diterapkan dalam bidang lain yang memiliki waktu awal (starting time) dan waktu akhir (ending time) suatu peristiwa/ kejadian seperti lama waktu pengunjung berada di sebuah perpustakaan.

\section{Unit Pelaksana Teknis (UPT)} Perpustakaan Universitas Syiah Kuala (Unsyiah) Banda Aceh merupakan salah satu perpustakaan terbesar di Provinsi Aceh dengan koleksi sebanyak sebanyak 75.114 judul atau 136.925 eksemplar. Koleksi tersebut tersebar dalam berbagai jenis, meliputi buku teks, terbitan berkala (jurnal), laporan akhir, skripsi, tesis, disertasi, majalah, buku referensi, laporan penelitian, CD-ROM dan dokumentasi. Koleksi pada perpustakaan juga tidak hanya terbatas pada koleksi tercetak saja, namun perpustakaan juga telah berlangganan e-book dan e-journal pada beberapa penerbit internasional (UPT.

Visitor Behavior in the Library of Syiah Kuala University based on 
Perpustakaan Unsyiah, 2015). Ketersedian berbagai jenis koleksi perpustakaan merupakan hal yang penting. Sebuah studi menunjukan bahwa koleksi yang dimanfaatkan pengguna sebagian besar pengunjung adalah majalah/jurnal, buku tercetak, dan buku elektronik, sedangkan penggunaan jurnal elektronik online dan offline cenderung masih sedikit (Rufaidah, 2013). UPT. Perpustakaan Unsyiah terdiri dari 3 lantai dengan koleksi yang berbeda-beda. Dalam beberapa tahun belakangan ini, UPT. Perpustakaan Unsyiah terus melakukan berbagai inovasi dalam upaya meningkatkan pelayanan dan kenyamanan kepada para anggota dan pengunjungnya termasuk dalam hal desain interior. Terdapat pengaruh secara simultan yang ditimbulkan oleh desain interior yang meliputi ruang, variasi, hirarki, area personal, pencahayaan, tata suara, suhu udara, perawatan, kualitas udara, gaya dan fashion terhadap kenyamanan pengguna di perpustakaan (Sainttyauw, 2013). Perubahanperubahan baru yang kreatif dan inovatif juga dilakukan oleh UPT. Perpustakaan Unsyiah, mulai dari program relax and easy, libricafe, jam layanan tambahan yang berlangsung sampai akhir pekan dan lain sebagainya. SNP (Standar Nasional Perpustakaan) No. 010 tahun Visitor Behavior in the Library of Syiah Kuala University based on Their Visiting Time Duration
2011 menyebutkan perpustakaan menyediakan layanan kepada pemustaka sekurang-kurangnya empat puluh jam per minggu, minimal 5 hari kerja perminggu (SNP, 2011). UPT. Perpustakaan Unsyiah memiliki waktu layanan yang melebihi standar tersebut, yaitu mulai dari pukul 08.30 - 23.00 WIB untuk hari Senin - Jum'at. Waktu layanan tersebut terbagi atas dua sesi. Pertama, sesi layanan reguler mulai dari pukul 08.30 17.00 WIB. Sesi kedua layanan tambahan, yaitu sore mulai pukul 17.00 18.30 WIB dan malam mulai dari pukul 19.30 - 23.00 WIB. Selain itu, waktu layanan juga ditambah pada hari Sabtu dan Minggu masing-masing mulai dari pukul 09.00 - 18.30 WIB dan $14.00-$ 18.30 WIB. Waktu jeda istirahat merupakan salah satu waktu favorit kunjungan ke perpustakaan. Sebagian besar pengunjung memanfaatkan waktu istirahat untuk akses ke perpustakaan (Nurlela, dkk, 2004). Dengan adanya perubahan dan inovasi-inovasi tersebut, tidak mengherankan apabila UPT. Perpustakaan Unsyiah memperoleh akreditasi "A" untuk kedua kalinya dari Lembaga Perpustakaan Nasional Republik Indonesia yang berlaku sampai dengan tanggal 28 Juni 2019 mendatang.

Pengunjung UPT. Perpustakaan

Unsyiah terdiri dari berbagai kalangan, 121 
mulai dari pelajar, mahasiswa, dosen hingga kalangan masyarakat umum lainnya. Kegiatan yang dilakukan pengunjung juga bervariasi mulai dari membaca, mengerjakan tugas, diskusi, mengisi waktu luang dan kegiatan lainnya. Hal ini sesuai dengan fungsi perpustakaan itu sendiri, antara lain adalah fungsi pendidikan dan pembelajaran, informasi, penelitian, rekreasi, dan preservasi (Rangkuti, 2014). Lamanya waktu kunjungan yang dihabiskan di perpustakaan berbeda-beda antar setiap pengunjungnya. Perbedaan waktu kunjungan ini disebabkan oleh berbagai faktor, salah satunya seperti kegiatan yang mereka lakukan di perpustakaan telah selesai. Mempelajari perilaku pengunjung berdasarkan lama waktu kunjungan mereka di UPT. Perpustakaan Unsyiah merupakan sebuah permasalahan yang menarik untuk diteliti. UPT. Perpustakaan Unsyiah dapat menggunakan hasil penelitian ini sebagai salah satu bahan acuan dalam penyusunan kebijakan di masa yang akan datang. Berdasarkan latar belakang tersebut, dapat dirumuskan sebuah permasalahan yaitu bagaimanakah perilaku pengunjung UPT. Perpustakaan Unsyiah berdasarkan lama waktu kunjungan yang mereka lakukan yang dilihat dari fungsi probabilitas, survival dan hazard.

\section{Kajian Literatur}

\section{Analisis Survival}

Masa hidup (life time) dari sebuah unit adalah panjang interval waktu, $T$, dari waktu pertama kali unit tersebut hidup atau bekerja (initial time) sampai dengan waktu saat unit tersebut mengalami kegagalan fungsi. Variabel waktu $T$ didefenisikan sebagai suatu random variabel karena lamanya masa hidup tersebut tidak bisa diprediksi secara tepat. Distribusi probabilitas kumulatif $(C D F)$ dari variabel $T$ adalah peluang masa hidup unit tersebut yang tidak melebihi dari waktu $t$, biasanya disimbolkan dengan $F(t)$. Adapun secara matematis, $F(t)$ dapat ditulis dengan

$$
F(t)=P\{T \leq t\} \text {, untuk } 0<t<\infty .
$$

Sementara fungsi probabilitas densitas $(P D F)$ adalah sebuah fungsi yang bernilai non negatif yang disimbolkan dengan $f(t)$. PDF dihitung dengan melakukan diferensiasi fungsi $C D F$. Selain dalam bentuk peluang, fungsi $C D F$ juga dapat ditulis dengan persamaan

$$
F(t)=\int_{0}^{t} f(x) d x, \text { untuk } 0 \leq t<\infty,
$$

sehingga fungsi $P D F$ dapat dituliskan dalam persamaan

$$
f(t)=\frac{\partial}{\partial t} F(t)
$$


Selanjutnya, fungsi survival yang disimbolkan dengan $S(t)$ dari sebuah komponen yang memiliki distribusi hidup $F(t)$, secara matematis dapat ditulis dengan persamaan

$$
S(t)=1-F(t)=P\{T>t\} .
$$

Dengan kata lain, fungsi survival adalah peluang sebuah unit memiliki masa hidup yang melebihi waktu $t$. Fungsi penting lainnya yang berkaitan dengan analisis survival adalah fungsi hazard yang disimbolkan dengan $h(t)$. Fungsi ini menjelaskan laju kegagalan seketika dari sebuah unit yang telah memiliki masa hidup $t$ satuan waktu, atau dapat ditulis dalam persamaan matematis

$$
h(t)=\lim _{\Delta \rightarrow 0} \frac{F(t+\Delta)-F(t)}{\Delta P\{T>t\}}=\frac{f(t)}{R(t)} .
$$

Formula tersebut juga dapat ditulis dalam persamaan

$$
\begin{aligned}
& h(t)=-\frac{d}{d t} \ln S(t), \text { dimana } \\
& S(t)=-\exp \left\{-\int_{o}^{t} h(x) d x\right\}
\end{aligned}
$$

(Zacks, 1991).

\section{Graphical Analysis}

Graphical analysis adalah salah satu teknik yang bisa digunakan untuk mengestimasi distribusi peluang suatu kumpulan data. Tujuan utama dari analisis ini adalah untuk memperoleh verifikasi grafik secara cepat mengenai distribusi peluang mana yang cocok dengan data yang dimiliki. Teori probabilitas klasik menyatakan bahwa empirikal $C D F, F_{n}(x)$, akan konvergen menuju $F(x)$ dalam probabilitas ketika jumlah sampel $(n)$ menjadi semakin besar. Hal ini berarti bahwa untuk jumlah sampel yang sangat banyak, maka empirikal $C D F$ akan mendekati $C D F$ yang sebenarnya dengan probabilitas yang tinggi. Sehingga untuk menentukan distribusi peluang suatu kumpulan data dapat dilakukan plotting antara empirikal $C D F$ dengan $C D F$ yang sebenarnya. Dimana nilai empirikal $C D F$ dapat didekati dengan nilai $x(i)$ yang merupakan fraksi ke- $\frac{i}{n}$ dari empirikal distribusi $F_{n}(x)$. Sehingga apabila $x(i)$ merupakan order statistik dari suatu random sampel dari sebuah distribusi $F(x)$, maka poin yang terbentuk dari koordinat $\left(F^{-1}(i / n), x(i)\right)$, untuk $i=1$, $2, \ldots, n$, akan tersebar disekitar garis lurus persamaan regresi dengan slope (lereng) sama dengan 1 yang melewati daerah asal. Lebih lanjut, jika $C D F$ sebenarnya adalah $F\left(\frac{x-\mu}{\sigma}\right)$, dimana $\quad x_{p}=\mu+$ $\sigma F^{-1}(p)$, maka poin $\quad(F((x-$ $\mu) / \sigma), x(i))$, untuk $i=1,2, \ldots, n$, akan tersebar disekitar garis lurus persamaan regresi dengan intercept $\mu$ dan slope $\sigma$. Metode least squares digunakan untuk mengestimasi nilai intercept dan slope dari kumpulan poin data tersebut. 
Koordinat poin yang digunakan untuk membangun model regresi linear dengan metode least squares berbeda antar satu distribusi peluang dengan distribusi peluang lainnya.

Koordinat yang dibutuhkan dalam graphical analysis untuk beberapa distribusi peluang adalah sebagai berikut:

1. Distribusi peluang eksponensial $x(i)$ dan $E_{i, n}$, dimana $E_{i, n}=-\ln \left(1-\frac{i}{n+1}\right)$, untuk $i=1,2, \ldots, n$.

2. Distribusi peluang weibull

$$
\begin{aligned}
& y_{i}=\ln x(i) \text { dan } u_{i, n}, \\
& \text { dimana } \quad u_{i, n}=\ln \left(-\ln \left(1-\frac{i}{n+1}\right)\right), \\
& \text { untuk } i=1,2, \ldots, n
\end{aligned}
$$

3. Distribusi peluang normal

$x(i)$ dan $z_{i, n}$,

dimana $z_{i, n}=\phi^{-1}\left(\frac{i-\frac{3}{8}}{n+\frac{1}{4}}\right)$, untuk $i=1$,

$2, \ldots, n$.

4. Distribusi peluang log normal

$y_{i}=\ln x(i) \operatorname{dan} z_{i, n}$,

dimana $z_{i, n}=\phi^{-1}\left(\frac{i-\frac{3}{8}}{n+\frac{1}{4}}\right)$, untuk $i=1$,

2, ..., $n$ (Zacks, 1991).

\section{Regresi Linear Sederhana}

Analisis regresi adalah salah satu metode statistik yang sering digunakan untuk melihat pengaruh variabel penjelas (x) terhadap variabel respon (y). Model regresi linear sederhana merupakan model regresi dengan sebuah variabel penjelas dan sebuah variabel respon. Model tersebut dapat ditulis dalam persamaan matematis:

$$
y=\beta_{0}+\beta_{1} x+e
$$

dimana $\beta_{0}, \beta_{1}$ dan $e$ merupakan intercept, slope, dan error dari model regresi. Intercept menunjukan nilai ratarata variabel respon ketika variabel penjelasnya bernilai nol. Sedangkan slope menunjukan besarnya perubahan nilai rata-rata variabel respon untuk setiap kenaikan satu satuan nilai dari variabel penjelasnya. Intercept dan slope dari model regresi dapat diestimasi dengan menggunakan metode least squares, dan masing-masing dapat dihitung melalui persamaan:

$$
\begin{aligned}
& \beta_{0}=\bar{y}-\beta_{1} \bar{x} \\
& \beta_{1}=\frac{\sum x y-\frac{\left(\sum x\right)\left(\sum y\right)}{n}}{\sum x^{2}-\frac{\left(\sum x\right)^{2}}{n}} .
\end{aligned}
$$

Koefisien determinasi $\left(R^{2}\right)$ menunjukan besarnya variabilitas variabel respon yang dapat dijelaskan oleh variabel penjelas. Sebuah model regresi yang baik memiliki nilai koefisien determinasi yang tinggi. Secara matematis, koefisien determinasi dapat ditulis dengan persamaan

$$
R^{2}=\left(\frac{n\left(\sum x y\right)-\left(\sum x\right)\left(\sum y\right)}{\sqrt{\left[\left(n \sum x^{2}\right)-\left(\sum x\right)^{2}\right]\left[\left(n \sum y^{2}\right)-\left(\sum y\right)^{2}\right]}}\right)^{2}
$$


dengan $\hat{y}$ adalah nilai estimasi variabel respon melalui model regresi. Adjusted $R^{2},\left(\bar{R}^{2}\right)$, merupakan ukuran yang lebih baik dalam menilai besarnya koefisien determinasi dari sebuah model regresi. Hal ini dikarenakan $\bar{R}^{2}$ hanya memasukkan variabel penjelas yang berkontribusi secara signifikan saja dalam proses perhitungan koefisien determinasinya. Adjusted $R^{2}$ dapat ditulis dalam persamaan matematis:

$$
\bar{R}^{2}=\left(R^{2}-\frac{p}{n-1}\right)\left(\frac{n-1}{n-(p+1)}\right)
$$

(Bowerman, dkk, 2005).

\section{Distribusi Eksponensial dalam Analisis Survival}

Ada beberapa distribusi peluang yang sering dipakai dalam analisis survival, diantaranya distribusi eksponensial, weibull, normal, $\log$ normal, dan beberapa distribusi lainnya. Distribusi eksponensial adalah salah satu distribusi peluang yang paling sering digunakan dalam analisis survival. Distribusi eksponesial memiliki sebuah parameter yang disimbolkan dengan $\lambda$ dan biasanya ditulis dengan $T \sim \operatorname{Exp}(\lambda)$. Fungsi probabilitas densitas $(P D F)$ untuk distribusi eksponensial ditulis dalam persamaan matematis:

$$
f(t)=\left\{\begin{array}{c}
\lambda \exp (-\lambda t), \text { untuk } t>0, \lambda>0 \\
0, \text { untuk nilai } t \text { dan } \lambda \text { lainnya }
\end{array}\right.
$$

(Rausand, dkk, 2004).
Sebagai tambahan, distribusi eksponensial merupakan kasus khusus dari distribusi weibull. Distribusi weibull sendiri memiliki dua buah parameter, parameter skala $(\lambda)$ dan parameter ketajaman $(\kappa)$, dan biasanya ditulis dengan $T \sim$ Weibull $(\lambda, \kappa)$. Distribusi weibull akan menjadi distribusi eksponensial apabila nilai parameter $\kappa=$ 1 yang menyebabkan fungsi hazard menjadi tetap/ konstan terhadap waktu (Stevenson, 2007). Fungsi hazard yang konstan terhadap waktu tersebut merupakan salah satu ciri penting dari distribusi eksponensial. Tabel 1 memuat persamaan fungsi probabilitas densitas $(P D F)$, probabilitas kumulatif $(C D F)$, fungsi survival dan fungsi hazard dari distribusi eksponensial (Zacks, 1991).

Tabel 1. Fungsi survival berdasarkan distribusi eksponensial

\begin{tabular}{cccc}
\hline $\boldsymbol{f}(\boldsymbol{t})$ & $\boldsymbol{F}(\boldsymbol{t})$ & $\boldsymbol{S}(\boldsymbol{t})$ & $\boldsymbol{h}(\boldsymbol{t})$ \\
\hline$\lambda \exp (-\lambda t)$ & $1-\exp (-\lambda t)$ & $\exp (-\lambda t)$ & $\lambda$ \\
\hline
\end{tabular}

\section{Metode Penelitian}

Penelitian ini dilakukan di UPT. Perpustakaan Universitas Syiah Kuala (Unsyiah) Banda Aceh pada tanggal 9 22 Desember 2016. Penelitian ini merupakan jenis penelitian kuantitatif dengan menggunakan data primer yang dihimpun melalui wawancara langsung 
dengan para pengunjung perpustakaan.

Sampel pengunjung yang diwawancarai diambil dengan menggunakan teknik sampling non-probability, yaitu sampling incidental sebanyak 35 orang pengunjung untuk masing-masing lantai. Sehingga jumlah total sampel secara keseluruhan adalah berjumlah 105 orang pengunjung. Adapun variabel yang digunakan dalam penelitian ini adalah lama waktu kunjungan di perpustakaan $(T)$, jenis kelamin, dan fakultas asal pengunjung tersebut. Metode analisis statistik yang digunakan dalam penelitian ini adalah analisis survival yang terdiri dari fungsi $P D F, C D F$, fungsi survival dan fungsi hazard. Tujuan penggunaan metode ini adalah untuk mengetahui perilaku pengunjung yang berkaitan dengan lama waktu kunjungan di UPT. Perpustakaan Unsyiah. Pengolahan data dengan analisis survival menggunakan software $R$ Versi 3.2.2.

Adapun langkah-langkah yang dilakukan dalam penelitian ini secara garis besar terbagi ke dalam 2 tahapan.

1. Melakukan estimasi distribusi peluang dari data lama waktu kunjungan di UPT. Perpustakaan Unsyiah dengan menggunakan metode graphical analysis.
2. Melakukan estimasi fungsi probabilitas densitas $(P D F)$, fungsi probabilitas kumulatif $(C D F)$, fungsi survival dan fungsi hazard berdasarkan distribusi peluang yang bersesuaian pada tahap pertama.

\section{Hasil Dan Pembahasan}

Waktu kedatangan para pengunjung di UPT. Perpustakaan Unsyiah disebut dengan starting time atau time origin, sedangkan waktu ketika pengunjung tersebut meninggalkan perpustakaan disebut dengan ending time. Oleh karena itu, data lama waktu kunjungan di UPT. Perpustakaan Unsyiah merupakan data survival yang dapat dianalisa dengan menggunakan metode survival untuk melihat perilaku pengunjung UPT. Perpustakaan Unsyiah yang berkaitan dengan lama waktu kunjungan yang dilakukan.

\section{Karakteristik Sampel Penelitian}

Sampel yang menjadi objek penelitian ini adalah pengunjung (mahasiswa dan mahasiswi) yang mengunjungi UPT. Perpustakaan Unsyiah pada saat pengambilan data dilakukan. Karakteristik sampel pengunjung berdasarkan jenis kelamin dan asal fakultas pengunjung dapat dilihat pada Tabel 2. 
Tabel 2. Karakteristik pengunjung UPT. Perpustakaan Unsyiah berdasar jenis kelamin dan fakultas

\begin{tabular}{|c|c|c|c|c|c|c|c|c|}
\hline \multirow{2}{*}{ Variabel } & \multicolumn{2}{|c|}{ Lantai 1} & \multicolumn{2}{|c|}{ Lantai 2} & \multicolumn{2}{|c|}{ Lantai 3} & \multicolumn{2}{|c|}{ Total } \\
\hline & $\mathbf{N}$ & $\%$ & $\mathbf{N}$ & $\%$ & $\mathbf{N}$ & $\%$ & $\mathbf{N}$ & $\%$ \\
\hline \multicolumn{9}{|l|}{ Jenis Kelamin } \\
\hline Laki-Laki & 7 & 20,00 & 8 & 22,86 & 17 & 48,57 & 32 & 30,48 \\
\hline Perempuan & 28 & 80,00 & 27 & 77,14 & 18 & 51,43 & 73 & 69,52 \\
\hline \multicolumn{9}{|l|}{ Fakultas } \\
\hline FEB & 3 & 8,57 & 2 & 5,71 & 2 & 5,71 & 7 & 6,67 \\
\hline FISIP & 7 & 20,00 & - & 0,00 & 3 & 8,57 & 10 & 9,52 \\
\hline FKEP & 3 & 8,57 & - & 0,00 & - & 0,00 & 3 & 2,86 \\
\hline FKH & 3 & 8,57 & - & 0,00 & 1 & 2,86 & 4 & 3,81 \\
\hline FKIP & 8 & 22,86 & 5 & 14,29 & 5 & 14,29 & 18 & 17,14 \\
\hline MIPA & 5 & 14,29 & 12 & 34,29 & - & 0,00 & 17 & 16,19 \\
\hline $\mathrm{FH}$ & 1 & 2,86 & 2 & 5,71 & - & 0,00 & 3 & 2,86 \\
\hline FT & 2 & 5,71 & 2 & 5,71 & 18 & 51,43 & 22 & 20,95 \\
\hline FK & - & 0,00 & 5 & 14,29 & - & 0,00 & 5 & 4,76 \\
\hline FKP & - & 0,00 & - & 0,00 & 3 & 8,57 & 3 & 2,86 \\
\hline FP & 2 & 5,71 & 7 & 20,00 & 3 & 8,57 & 12 & 11,43 \\
\hline PPs & 1 & 2,86 & - & 0,00 & - & 0,00 & 1 & 0,95 \\
\hline
\end{tabular}

Berdasarkan Tabel 2, diketahui bahwa pengunjung yang menjadi sampel penelitian ini berjumlah 105 orang, dengan perincian sebanyak 73 orang berjenis kelamin perempuan $(69,52 \%)$ dan sisanya 32 orang $(30,48 \%)$ berjenis kelamin laki-laki. Hal ini menunjukan bahwa pada umumnya mahasiswi lebih rajin berkunjung dan menghabiskan waktu mereka di perpustakaan dari pada mahasiswa. Pengunjung tersebut merupakan mahasiswa dan mahasiswi yang berasal dari 11 fakultas serta satu program pasca sarjana yang ada di lingkungan Universitas Syiah Kuala. Jika di lihat berdasarkan asal fakultas, maka pengunjung paling banyak berasal dari Fakultas Teknik (FT) dengan jumlah sebanyak 22 orang (20,95\%), kemudian disusul oleh Fakultas Keguruan dan Ilmu
Pengetahun (FKIP) dan Fakultas Matematika dan Ilmu Pengetahuan Alam (MIPA) dengan jumlah masing-masing sebanyak 18 orang $(17,14 \%)$ dan 17 orang (16,19\%). Sedangkan sisanya berasal dari Fakultas Pertanian (FP), Fakultas Ilmu Sosial dan Ilmu Pemerintahan (FISIP), Fakultas Ekonomi dan Bisnis (FEB), Fakultas Kedokteran (FK), Fakultas Kedokteran Hewan (FKH), Fakultas Keperawatan (FKEP), Fakultas Hukum (FH), Fakultas Kelautan dan Perikanan (FKP), dan Program Pasca Sarjana (PPs). Jumlah pengunjung tersebut berbanding lurus dengan jumlah mahasiswa Unsyiah aktif berdasarkan asal fakultasnya. Selain itu, perbedaan jumlah pengunjung antar fakultas ini juga bisa disebabkan oleh ketersediaan koleksi buku di perpustakaan fakultas mereka 
masing-masing. Jika dilihat secara lebih rinci, pengunjung yang berasal dari FT cenderung lebih suka berkunjung ke lantai 3. Kemudian, pengunjung yang berasal dari FMIPA lebih dominan menghabiskan waktu di lantai 2. Sedangkan lantai 1 merupakan tempat favorit bagi hampir seluruh pengunjung, terutama yang berasal dari FKIP, FISIP, dan FMIPA.

\section{Penentuan Distribusi Peluang Melalui} Graphical Analysis

Graphical analysis digunakan untuk mengestimasi distribusi peluang data lama kunjungan di UPT. Perpustakaan Unsyiah. Terdapat 4 macam distribusi peluang yang diujikan yaitu: distribusi eksponensial (a), weibull (b), normal (c) dan log normal (d). Distribusi peluang yang paling cocok dengan data lama kunjungan di UPT. Perpustakaan Unsyiah adalah distribusi yang memiliki model regresi linear dengan nilai adjusted $R^{2}$ terbesar. Dalam kasus ini, nilai adjusted $R^{2}$ menunjukan seberapa besar tingkat kecocokan nilai empirikal $C D F$ terhadap nilai $C D F$ sebenarnya. Sehingga nilai adjusted $R^{2}$ yang besar akan mengidentifikasikan bahwa data lama kunjungan di UPT. Perpustakaan Unsyiah cocok dengan distribusi peluang yang diujikan tersebut.
Berikut adalah graphical analysis untuk keempat distribusi peluang yang diujikan. Parameter model regresi linear berupa intercept dan slope dihitung dengan menggunakan metode least squares untuk setiap kumpulan data poin yang terbentuk melalui koordinat yang bersesuaian untuk masing-masing distribusi peluangnya.

Gambar 1 menyajikan output graphical analysis untuk keempat distribusi peluang yang diujikan dengan menggunakan software $R$. Data point yang terbentuk dari koordinat yang bersesuai dengan masing-masing distribusi peluang digambarkan dengan simbol " $o$ " dan garis diagonal merah menunjukan garis model regesi linear yang dibentuk melalui metode least squares. Parameter dari model regresi linear untuk setiap distribusi peluang tersebut disajikan pada Tabel 3.

Tabel 3 menyajikan beberapa parameter penting dari masing-masing distribusi peluang dalam graphical analysis. Parameter tersebut antara lain adalah intercept, slope dan adjusted $R^{2}$ dengan persamaan pada sub bagian 2.3. Berdasarkan tabel tersebut diketahui bahwa distribusi peluang yang memiliki nilai adjusted $R^{2}$ yang paling besar adalah distribusi eksponensial dengan nilai adjusted $R^{2}$ sebesar 0,9628 . Model regresi Visitor Behavior in the Library of Syiah Kuala University based on Their Visiting Time Duration 


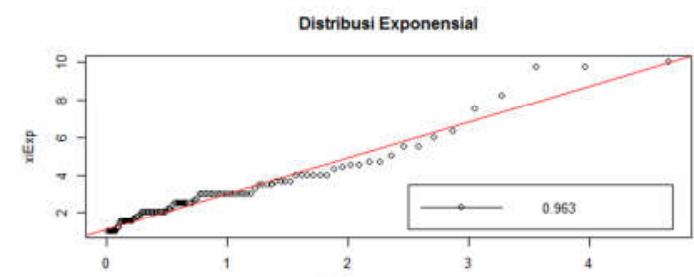

(a) En

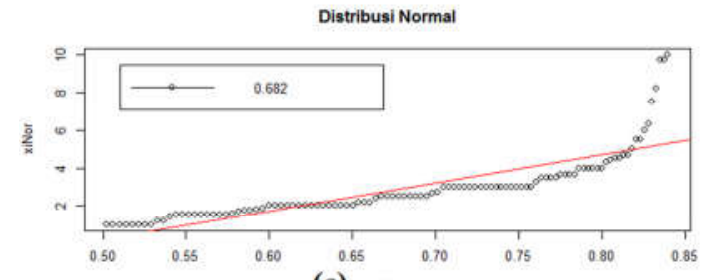

(c) zinkor

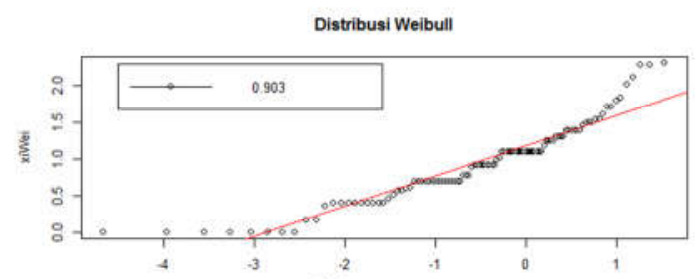

(b) un

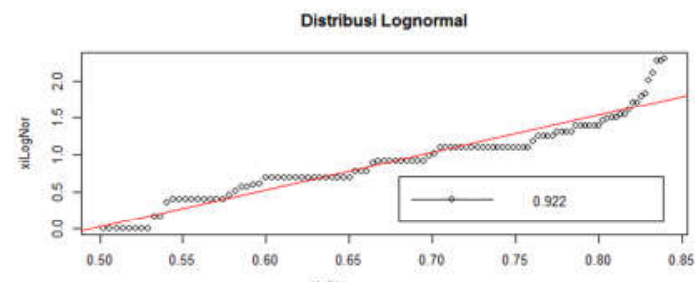

(d) zinlog

Gambar 1. Graphical analysis data lama waktu kunjungan di UPT. Perpustakaan Unsyiah

Tabel 3. Parameter model regresi linear dari distribusi peluang

\begin{tabular}{lcccc}
\hline Statistik & Eksponensial & Weibull & Normal & Log Normal \\
\hline Intercept & 1,1203 & 1,1794 & $-7,2075$ & $-2,5054$ \\
Slope & 1,9015 & 0,4118 & 14,8868 & 5,0465 \\
Adjusted $R^{2}$ & 0,9628 & 0,9027 & 0,6819 & 0,9224 \\
\hline
\end{tabular}

linear dengan distribusi eksponensial tersebut memiliki parameter intercept sebesar 1,1203 dan slope sebesar 1,90152. Parameter tersebut berguna dalam menghitung parameter data lama waktu kunjungan di UPT. Perpustakaan Unsyiah dengan menggunakan distribusi eksponensial dan fungsi-fungsi yang berkaitan dengan analisis survival.

\section{Analisis Survival}

\section{Statistik Deskriptif Lama Waktu}

\section{Kunjungan}

Variabel utama yang menjadi fokus dalam penelitian ini adalah lama waktu (jam) kunjungan di UPT. Perpustakaan Unsyiah. Data lama waktu kunjungan yang dihimpun disetiap lantai kemudian diurutkan dari yang bernilai paling kecil hingga yang bernilai paling besar (order statistik) untuk melihat gambaran lamanya waktu kunjungan di UPT. Perpustakaan Unsyiah. Selain digambarkan untuk setiap lantainya, data tersebut juga digabungkan dan diurutkan untuk melihat gambaran lama kunjungan di UPT. Perpustakaan Unsyiah secara keseluruhan. Plot sebaran data lama waktu kunjungan sampel pengunjung di UPT. Perpustakaan Unsyiah untuk masing-masing lantai dan secara keseluruhan dapat dilihat pada Gambar 2. 

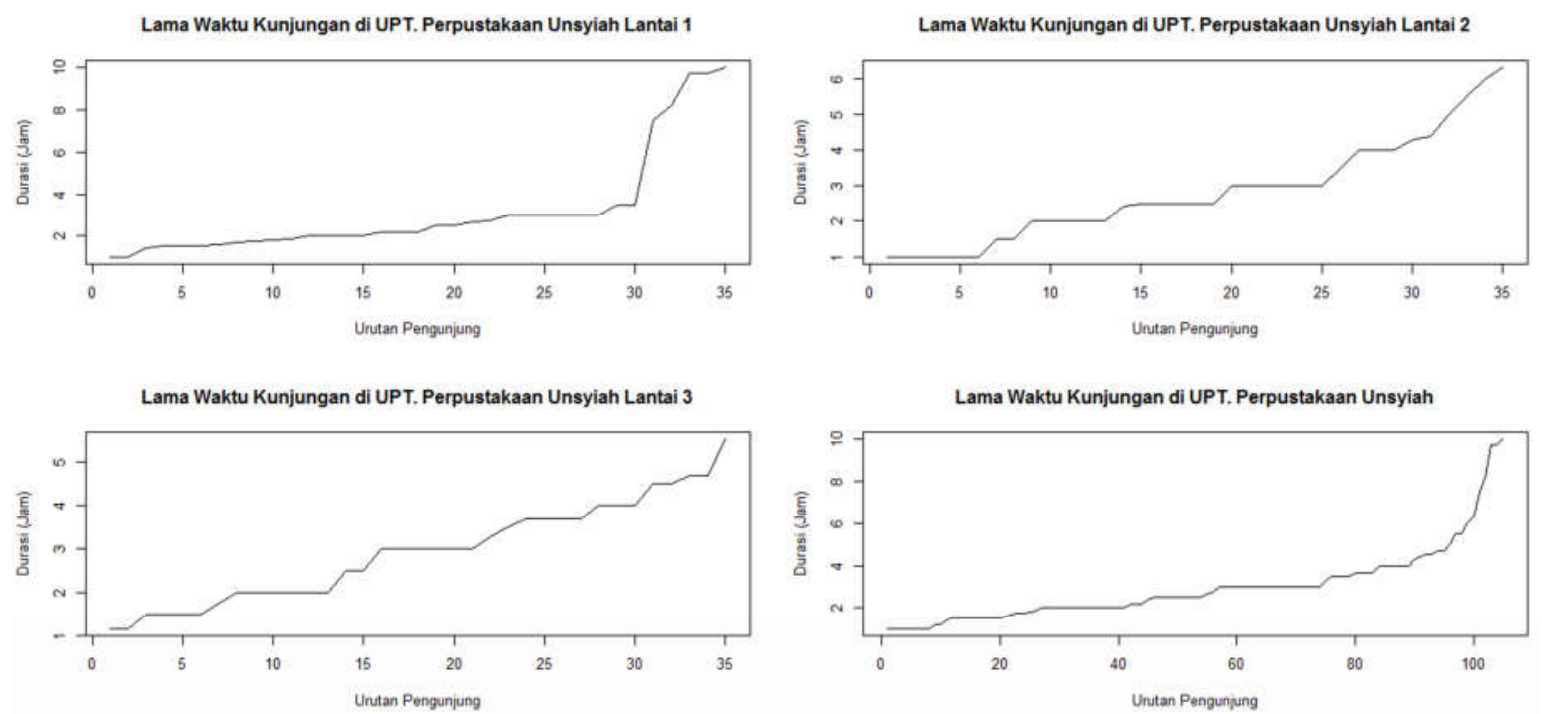

Gambar 2. Plot sebaran data lama waktu kunjungan di UPT. Perpustakaan Unsyiah

Tabel 4. Statistik deskriptif lama kunjungan (jam) di UPT. Perpustakaan Unsyiah

\begin{tabular}{lcccccc}
\hline & Min & Kuantil 1 & Rata-Rata & Median & Kuantil 3 & Mak \\
\hline Lantai 1 & 1,00 & 1,78 & 3,19 & 2,17 & 3,00 & 10,00 \\
Lantai 2 & 1,00 & 2,00 & 2,83 & 2,50 & 3,75 & 6,30 \\
Lantai 3 & 1,17 & 2,00 & 2,93 & 3,00 & 3,67 & 5,50 \\
Keseluruhan & 1,00 & 2,00 & 2,98 & 2,50 & 3,50 & 10,00 \\
\hline
\end{tabular}

Selain itu, data lama waktu kunjungan di UPT. Perpustakaan Unsyiah juga dapat digunakan untuk menghitung beberapa statistik penting yang dapat menggambarkan ringkasan data penelitian. Table 4 menyajikan ringkasan beberapa statistik penting dari data lama waktu kunjungan di UPT. Perpustakaan Unsyiah untuk masingmasing lantai dan secara keseluruhannya.

Berdasarkan Tabel 4, diketahui bahwa secara keseluruhan lama waktu minimal yang dihabiskan pengunjung di UPT. Perpustakaan Unsyiah adalah selama 1,00 jam dengan nilai maksimalnya selama 10,00 jam. Visitor Behavior in the Library of Syiah Kuala University based on Their Visiting Time Duration
Selanjutnya, rata-rata lama waktu yang dihabiskan pengunjung adalah selama 2,98 jam dengan nilai median selama 2,50 jam. Jika dilihat secara lebih rinci, rata-rata lama waktu kunjungan di lantai 1 melebihi rata-rata lama waktu kunjungan secara keseluruhan. Sedangkan rata-rata lama waktu kunjungan di lantai 2 dan 3 masih lebih sedikit jika dibandingkan dengan ratarata lama waktu kunjungan keseluruhan sampel pengunjung di UPT. Perpustakaan Unsyiah.

Fungsi PDF, CDF, Survival dan Hazard Data Lama Waktu Kunjungan 130 
Berdasarkan graphical analysis yang telah dibahas pada sub bagian 4.2, diketahui bahwa data lama waktu kunjungan di UPT. Perpustakaan Unsyiah diestimasi memiliki distribusi eksponensial. Parameter distribusi eksponensial, $\lambda$, dapat diestimasi melalui nilai parameter slope model regresi linear dengan metode least squares yaitu sebesar 1,9015, atau dapat ditulis dengan $T \sim \operatorname{Exp}(1,9015)$. Beberapa parameter penting dari data lama waktu kunjungan dengan menggunakan distribusi eksponensial antara lain adalah mean, median, standar deviasi dan nilai $t_{0}$. Nilai parameter mean dan standar deviasi diestimasi melalui nilai parameter slope model regresi linear pada graphical analysis sebelumnya. Selanjutnya, nilai median diestimasi melalui persamaan regresi $\hat{x}(z)=$ intercept $+z \cdot$ slope dengan nilai z sebesar 0,693 , sedangkan nilai $t_{0}$ diestimasi melalui parameter intercept model linear (Zacks, 1991). Nilai mean, median, standar deviasi dan $t_{0}$ untuk distribusi eksponesial tersebut disajikan pada Tabel 5.

Tabel 5. Parameter data lama waktu kunjungan berdasarkan distribusi eksponensial

\begin{tabular}{|c|c|c|}
\hline $\begin{array}{l}\text { Rata- } \\
\text { Rata }\end{array}$ & Media & $\begin{array}{l}\text { Standar } \\
\text { Deviasi }\end{array}$ \\
\hline
\end{tabular}

\begin{tabular}{llll}
1,9015 & 2,4381 & 1,9015 & 1,1203 \\
\hline
\end{tabular}

Berdasarkan Tabel 5 diatas, diketahui bahwa nilai rata-rata dan standar deviasi lama waktu kunjungan di UPT. Perpustakaan Unsyiah yang diestimasi dengan menggunakan distribusi eksponensial adalah bernilai sama yaitu selama 1,9015 jam. Nilai standar deviasi yang besar menunjukan adanya perbedaan yang tinggi pada data lama waktu kunjungan di UPT. Perpustakaan Unsyiah antara satu pengunjung dengan pengunjung yang lainnya. Sedangkan nilai median lama waktu kunjungan tersebut diestimasi selama 2,4381 jam dan lama waktu kunjungan terkecil diestimasikan selama 1,1203 jam. Nilai median menunjukan bahwa 50,0\% pengunjung menghabiskan waktu selama kurang atau sama dengan 2,4381 jam, sedangkan 50,0\% lainnya menghabiskan lebih dari 2,4381 jam di perpustakaan. Median yang diestimasi berdasarkan distribusi eksponensial ini bernilai sangat dekat dengan nilai median dari data lama waktu kunjungan sebenarnya yaitu selama 2,50 jam

Dengan diketahuinya parameter dari distribusi peluang, maka fungsi probabilitas densitas $(P D F)$, fungsi probabilitas kumulatif $(C D F)$, fungsi survival dan fungsi hazard dapat dihitung

Visitor Behavior in the Library of Syiah Kuala University based on

Their Visiting Time Duration 
dengan persamaan yang terdapat pada

Tabel 1. Perilaku pengunjung perpustakaan dapat dilihat dari fungsi probabilitas, survival dan hazard dari data lama waktu kunjungan mereka di UPT. Perpustakaan Unsyiah. Nilai fungsi probabilitas densitas $(P D F)$ dapat dihitung melalui persamaan $f(t)=$ $\lambda \exp (-\lambda t) . \quad$ Fungsi probabilitas kumulatif $(C D F)$ dihitung melalui persamaan $F(t)=1-\exp (-\lambda t)$. Fungsi survival dapat dihitung melalui persamaan $S(t)=\exp (-\lambda t)$, dan fungsi hazard dapat dihitung melalui persamaan $h(t)=\lambda$.

Tabel 6 menyajikan nilai $P D F$, $C D F$, fungsi survival dan hazard dari data lama waktu kunjungan di UPT. Perpustakaan Unsyiah untuk seluruh pengunjung UPT. Perpustakaan Unsyiah yang menjadi sampel dalam penelitian ini. Nilai dari masing-masing fungsi dalam analisis survival tersebut juga dapat disajikan dalam bentuk grafik untuk menggambarkan secara lebih jelas mengenai perilaku pengunjung UPT. Perpustakaan Unsyiah berdasarkan lama waktu kunjungan mereka. Gambar 3 menyajikan grafik untuk masing-masing nilai $P D F, C D F$, fungsi survival dan hazard dari data lama waktu kunjungan di UPT. Perpustakaan Unsyiah.
Berdasarkan data dalam Tabel 6 yang digambarkan melalui Gambar 3.a, diketahui bahwa fungsi probabilitas densitas $(P D F)$ dari data lama waktu kunjungan di UPT. Perpustakaan Unsyiah cenderung menjadi semakin kecil seiring bertambahnya lama waktu kunjungan. Peluang seorang pengunjung berada di perpustakaan untuk lama waktu 1 jam adalah sebesar 0,3108 dan terus mengalami penurunan seiring bertambahnya lama waktu kunjungan. Peluang tersebut berada di bawah 0,1 pada saat lama waktu kunjungan lebih dari 3 jam. Kemudian akan terus menurun secara eksponensial hingga mencapai 0,0027 pada saat lama waktu kunjungan mencapai waktu maksimumnya yaitu selama 10 jam.

Fungsi probabilitas kumulatif $(C D F)$ dari data lama waktu kunjungan memiliki perilaku yang terbalik jika dibandingkan dengan PDF. Peluang kumulatif tersebut cenderung mengalami kenaikan terhadap waktu. Karena $C D F$ menghitung peluang dari titik awal (kedatangan) sampai dengan waktu $t$ jam yang dihabiskan di perpustakaan. Dengan kata lain, $C D F$ adalah peluang pengunjung berada di perpustakaan yang tidak melebihi waktu $t$ jam. Sebagai contoh, data dalam Tabel 6 menunjukkan bahwa peluang pengunjung berada di Visitor Behavior in the Library of Syiah Kuala University based on Their Visiting Time Duration

(Samsul Anwar, Afriyani, Putri Shalihatul Ula, Isra Safriana, Ida Fajri, Reza Ariska) 
perpustakaan tidak melebihi waktu 3 jam perpustakaan tidak melebihi waktu 4 jam adalah sebesar 0,7935, sedangkan adalah sebesar

0,8780 . peluang pengunjung berada di

Tabel 6. Nilai $P D F, C D F$, Fungsi Survival dan Hazard data lama waktu kunjungan

\begin{tabular}{|c|c|c|c|c|c|}
\hline $\begin{array}{c}\text { Lama Waktu } \\
\text { Kunjungan (jam) }\end{array}$ & $\begin{array}{c}\text { Frekuensi } \\
N\end{array}$ & $\begin{array}{l}P D F \\
f(t)\end{array}$ & $\begin{array}{l}C D F \\
F(t)\end{array}$ & $\begin{array}{c}\text { Survival } \\
S(t)\end{array}$ & $\begin{array}{c}\text { Hazard } \\
h(t)\end{array}$ \\
\hline 1,00 & 8 & 0,3108 & 0,4090 & 0,5910 & 0,5259 \\
\hline 1,17 & 2 & 0,2842 & 0,4595 & 0,5405 & 0,5259 \\
\hline 1,42 & 1 & 0,2492 & 0,5261 & 0,4739 & 0,5259 \\
\hline 1,50 & 9 & 0,2390 & 0,5456 & 0,4544 & 0,5259 \\
\hline 1,58 & 1 & 0,2291 & 0,5643 & 0,4357 & 0,5259 \\
\hline 1,67 & 1 & 0,2185 & 0,5845 & 0,4155 & 0,5259 \\
\hline 1,75 & 2 & 0,2095 & 0,6016 & 0,3984 & 0,5259 \\
\hline 1,80 & 1 & 0,2041 & 0,6119 & 0,3881 & 0,5259 \\
\hline 1,83 & 1 & 0,2009 & 0,6180 & 0,3820 & 0,5259 \\
\hline 2,00 & 15 & 0,1837 & 0,6507 & 0,3493 & 0,5259 \\
\hline 2,17 & 3 & 0,1680 & 0,6806 & 0,3194 & 0,5259 \\
\hline 2,42 & 1 & 0,1473 & 0,7199 & 0,2801 & 0,5259 \\
\hline 2,50 & 9 & 0,1412 & 0,7315 & 0,2685 & 0,5259 \\
\hline 2,67 & 1 & 0,1291 & 0,7544 & 0,2456 & 0,5259 \\
\hline 2,75 & 1 & 0,1238 & 0,7645 & 0,2355 & 0,5259 \\
\hline 3,00 & 18 & 0,1086 & 0,7935 & 0,2065 & 0,5259 \\
\hline 3,25 & 1 & 0,0952 & 0,8190 & 0,1810 & 0,5259 \\
\hline 3,50 & 4 & 0,0835 & 0,8413 & 0,1587 & 0,5259 \\
\hline 3,67 & 4 & 0,0763 & 0,8549 & 0,1451 & 0,5259 \\
\hline 4,00 & 6 & 0,0642 & 0,8780 & 0,1220 & 0,5259 \\
\hline 4,30 & 1 & 0,0548 & 0,8958 & 0,1042 & 0,5259 \\
\hline 4,40 & 1 & 0,0520 & 0,9011 & 0,0989 & 0,5259 \\
\hline 4,50 & 2 & 0,0493 & 0,9062 & 0,0938 & 0,5259 \\
\hline 4,67 & 2 & 0,0451 & 0,9142 & 0,0858 & 0,5259 \\
\hline 5,00 & 1 & 0,0379 & 0,9279 & 0,0721 & 0,5259 \\
\hline 5,50 & 2 & 0,0292 & 0,9446 & 0,0554 & 0,5259 \\
\hline 6,00 & 1 & 0,0224 & 0,9574 & 0,0426 & 0,5259 \\
\hline 6,30 & 1 & 0,0191 & 0,9636 & 0,0364 & 0,5259 \\
\hline 7,50 & 1 & 0,0102 & 0,9806 & 0,0194 & 0,5259 \\
\hline 8,25 & 1 & 0,0069 & 0,9869 & 0,0131 & 0,5259 \\
\hline 9,75 & 2 & 0,0031 & 0,9941 & 0,0059 & 0,5259 \\
\hline 10,00 & 1 & 0,0027 & 0,9948 & 0,0052 & 0,5259 \\
\hline
\end{tabular}

Visitor Behavior in the Library of Syiah Kuala University based on 


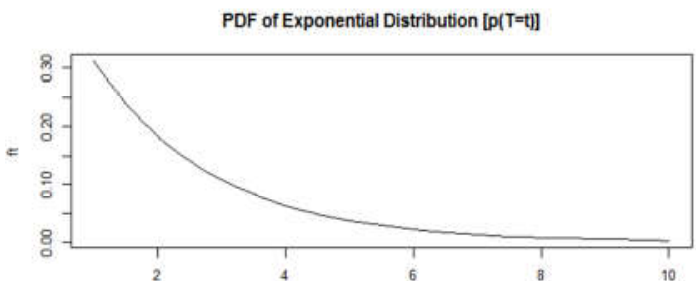

(a) waktu

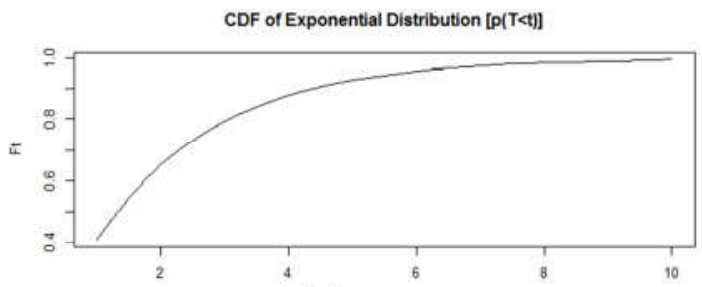

(c) waikt

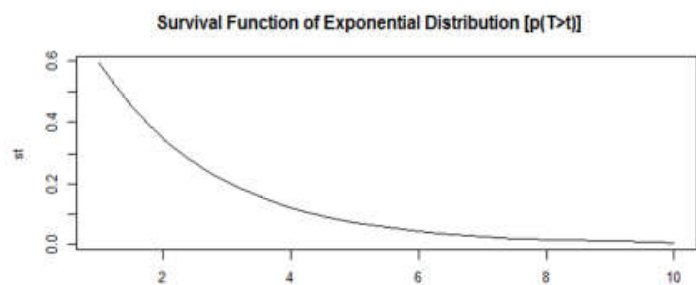

(b) waktu

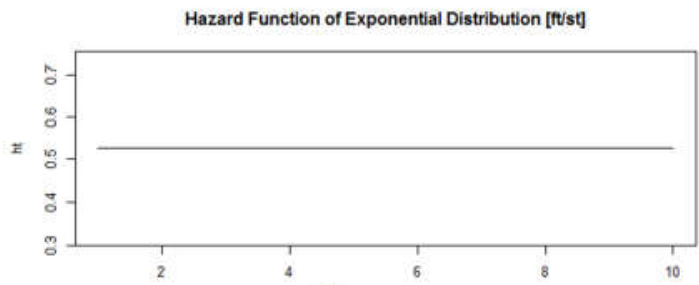

(d) waitu

Gambar 3. Grafik fungsi $P D F, C D F$, survival dan hazard data lama waktu kunjungan di UPT. Perpustakaan Unsyiah

$C D F$ memberikan peluang berada di perpustakaan akan turun keberadaan pengunjung di UPT. menjadi sebesar 0,3493. Lebih lanjut, Perpustakaan Unsyiah sampai dengan peluang tersebut akan berada dibawah 0,1 waktu tertentu, sedangkan fungsi survival menghitung peluang seorang pengunjung untuk tetap berada di perpustakaan setelah dia berada di sana dalam jangka waktu tertentu. Berdasarkan Tabel 6 dan Gambar 3.b, terlihat bahwa fungsi survival memiliki perilaku yang serupa dengan perilaku $P D F$. Peluang seorang pengunjung tetap berada di perpustakaan setelah dia berada di sana selama 1 jam adalah sebesar 0,5910. Peluang tersebut akan mengalami penurunan seiring bertambahnya lama waktu pengunjung berada di perpustakaan. Sebagai ilustrasi, setelah pengunjung berada di perpustakaan selama 2 jam, maka peluang pengunjung tersebut untuk tetap pada saat pengunjung telah berada di perpustakaan untuk lama waktu sekitar 4,30 jam. Peluang seorang pengunjung untuk tetap berada di perpustakaan setelah dia berada di sana selama 10 jam adalah sebesar 0,0052 .

Fungsi hazard menjelaskan laju kegagalan seketika dari seorang pengunjung yang telah berada di perpustakaan selama kurun waktu tertentu. Pengertian dari kegagalan dalam kasus ini adalah kejadian pengunjung meninggalkan perpustakaan seketika setelah pengunjung tersebut berada di sana selama waktu $t$ jam. Berdasarkan data dalam Tabel 6 dan Gambar 3.d, diketahui bahwa fungsi hazard memiliki 
nilai yang konstan terhadap waktu yaitu sebesar 0,5259. Hal ini memiliki arti bahwa fungsi hazard tidak dipengaruhi oleh durasi waktu $t$. Dengan kata lain, laju seorang pengunjung untuk keluar meninggalkan UPT. Perpustakaan Unsyiah seketika setelah waktu $t$, tidak dipengaruhi oleh lamanya waktu yang telah dihabiskan pengunjung tersebut di perpustakaan, dan pengunjung dapat meninggalkan perpustakaan kapan saja dengan rate sebesar 0,5259 .

\section{Kesimpulan}

Penelitian ini melibatkan 105 orang sampel pengunjung UPT. Perpustakaan Universitas Syiah Kuala (Unsyiah) Banda Aceh. Berdasarkan graphical analysis diketahui bahwa data lama waktu kunjungan di UPT. Perpustakaan Unsyiah adalah berdistribusi eksponensial dengan parameter $\lambda=1,9015$. Perilaku pengunjung perpustakaan berdasarkan lama waktu kunjungan yang mereka lakukan dapat di lihat dari fungsi probabilitas, survival dan hazard. Fungsi probabilitas densitas $(P D F)$ dari data lama waktu kunjungan cenderung menjadi semakin kecil seiring bertambahnya lama waktu kunjungan. Hal ini menunjukan bahwa kemungkinan pengunjung untuk berada di UPT. Visitor Behavior in the Library of Syiah Kuala University based on Their Visiting Time Duration
Perpustakaan Unsyiah akan semakin kecil seiring bertambahnya lama waktu kunjungan yang dilakukan. Sedangkan fungsi probabilitas kumulatif $(C D F)$ memiliki perilaku yang sebaliknya. Fungsi survival yang menghitung peluang seorang pengunjung untuk tetap berada di perpustakaan setelah dia berada disana dalam jangka waktu tertentu memiliki perilaku yang mirip dengan $P D F$. Dengan demikian, kemungkinan pengunjung untuk tetap bertahan di perpustakaan juga akan semakin kecil seiring bertambahnya lama waktu yang telah mereka habiskan di UPT. Perpustakaan Unsyiah. Terakhir, fungsi hazard memiliki nilai yang konstan terhadap waktu yaitu sebesar 0,5259 . Hal ini mengindikasikan bahwa laju seorang pengunjung untuk keluar meninggalkan UPT. Perpustakaan Unsyiah tidak dipengaruhi oleh lamanya waktu yang telah dihabiskan di perpustakaan. Dengan kata lain, pengunjung dapat meninggalkan UPT. Perpustakaan Unsyiah kapan saja dengan tingkat kelajuan yang sama.

\section{Referensi}

Bowerman, B.L., O’Connell, R.T., dan Koehler, A.B., 2005, Forecasting Time Series, and Regression, an Applied Approach, Edisi Keempat, California: Thomson. 
Kleinbaum, D. G., dan Klein, M., 2005, Survival Analysis, Edisi Kedua, New York: Springer Science Business Media, Inc.

Nurlela dan Maksum, 2004, Akses Informasi dan Persepsi Peserta Diklat Terhadap Jasa Perpustakaan, Jakarta, Kementrian Pertanian, Jurnal Perpustakaan Pertanian, 13, 33 - 40.

Rangkuti, L.A., 2014, Pentingnya Pendidikan Pemakai (User Education) di Perpustakaan Perguruan Tinggi, Medan, UIN Sumatera Utara, Jurnal Iqra', 8, 40 - 47.

Rausand, M., dan Hoyland, A., 2004, System Reliability Theory: Models, Satistical Methods and Applications, Edisi Kedua, New Jersey: Wiley\& sons, Inc.

Rufaidah, V.W., 2013, Pemetaan Kondisi Perpustakaan Digital UK/UPT Banda Litbang Pertanian, Jakarta, Kementrian Pertanian, Jurnal Perpustakaan Pertanian, 22, 50 - 58.

Sainttyauw, A., 2013, Pengaruh Desain Interion Perpustakaan terhadap Kenyamanan Pengguna di Perpustakaan Universitas 17 Agustus 1945 Surabaya, Surabaya, Universitas Airlangga, Jurnal Libri-Net, 2, 233 256.

SNP (Standar Nasional Perpustakaan)

Nomor 010 Tahun 2011:

Perpustakaan Perguruan Tinggi, Perpustakaan Nasional RI, (Online), http://www.perpusnas.go.id/assets/upl oads/2016/10/standar_nasional_perpu stakaan-sekolah.pdf. Diakses Tanggal 6 April 2017.

Stevenson, M., 2007, An Introduction to Survival Analysis, EpiCentre, IVABS, Massey University.

UPT. Perpustakaan Universitas Syiah Kuala, Rencana Strategis (RENSTRA) Tahun 2015-2018,

Visitor Behavior in the Library of Syiah Kuala University based on Their Visiting Time Duration

(Samsul Anwar, Afriyani, Putri Shalihatul Ula, Isra Safriana, Ida Fajri, Reza Ariska) http://library.unsyiah.ac.id/struktur/se jarah/. Diakses pada tanggal 27 Februari 2017.

Zacks, S., 1991, Introduction to Reliability Analysis Probability Models and Statistical Methods, New York: Springer text in Statistics. 